\title{
Per què es va congelar l'Àrtic?
}

\author{
Antoni Rosell \\ Institut de Ciència i Tecnologia Ambientals. Universitat Autònoma de Barcelona \\ Joan Aliberas \\ IES Josep Puig i Cadafalch. Mataró
}

Estudiar el clima que tenia la Terra milions d'anys enrere pot semblar una feina inútil, per poc interessant i per impossible; però no és així. Aquell clima ha deixat algunes pistes que han arribat fins a nosaltres. Si les sabem interpretar, podrem conèixer com era aquell clima $i$ per quins motius va evolucionar de la manera que ho va fer. I un cop coneguts aquests mecanismes, és possible millorar els models informàtics del clima perquè ens ajudin a preveure millor la seva evolució, comptant amb les pertorbacions que l'activitat humana hi està produint.

Fa 2,7 milions d'anys la Terra va entrar en una etapa de glaciacions. En relativament poc temps l'Oceà Àrtic es va gelar.

Què és el que va provocar aquest dràstic canvi de clima en les zones més septentrionals del planeta? Quines proves tenim de que les coses van anar així? I, finalment, aquest nou coneixement té alguna transcendència per a nosaltres?

\section{EL MECANISME DEL CANVI}

La causa inicial del desencadenament del procés ha de ser una aportació sobtada d'aigua dolça en la zona subàrtica de l'oceà Pacífic. Aquesta aigua podria provenir d'un augment de les precipitacions, de la fusió de gel marí, o d'una gran aportació d'aigua continentals.

És fàcilment comprovable que l'aigua dolça és menys densa que l'aigua salada (fig. 1).

Per aquest motiu, durant la primavera i l'estiu l'aigua dolça restava a la superfície de l'oceà, escalfant-se més que en altres condicions. I com més s'escalfava, més s'estratificava encara i més contribuïa a apujar la temperatura.

Quan arribava l'hivern, la temperatura superficial de l'oceà baixava. Això feia augmentar la seva densitat, fent-se més semblant a la de l'aigua salada. En aquestes condicions, el vent podia barrejar l'aigua superficial amb la profunda, fent que tota aquesta gran massa es refredés.

En definitiva, la superfície del mar a l'estiu s'escalfava més del normal per l'època, i a l'hivern també es refredava més. Es calcula que l'oscil-lació tèrmica entre estacions va augmentar $7^{\circ} \mathrm{C}$ en pocs segles.
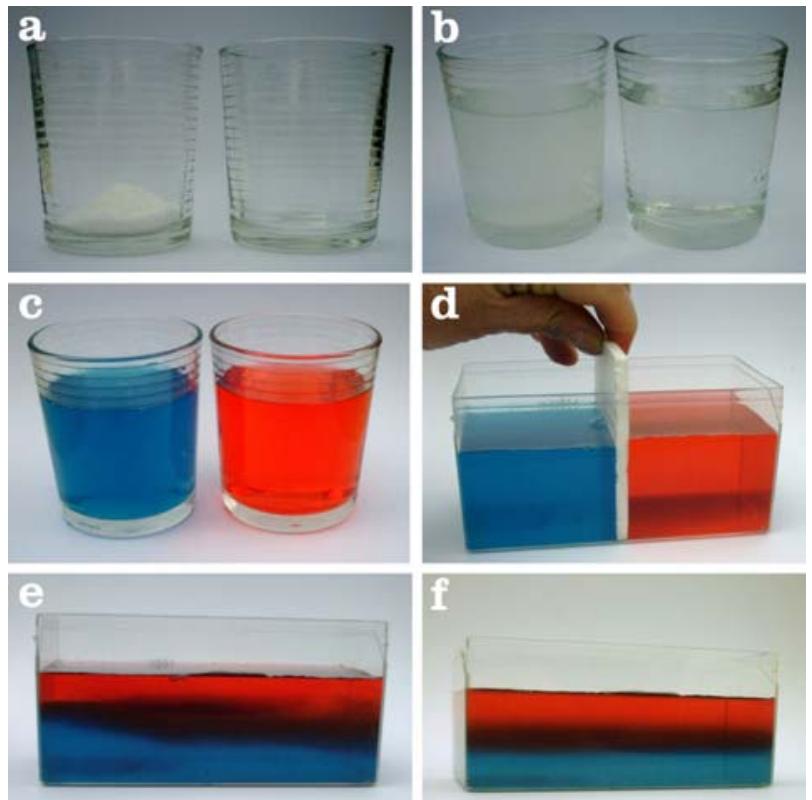

Fig. 1. Visualització de l'estratificació d'aigua dolça i salada a causa de la seva diferència de densitat.

El gran escalfament del mar durant l'estiu augmentava l'evaporació de l'aigua, mentre que el refredament del clima durant l'hivern, provocat per la baixa temperatura superficial de mar, feia precipitar tota aquesta humitat en forma de neu. 
D'aquesta manera, la part nord d'Amèrica i d'Euràsia es cobrí de gels permanents.

A més a més, l'augment de superfície nevada, amb un albedo més elevat, reflectia més radiació solar, provocant encara un descens més gran de la temperatura. L'Àrtic es glaçà a causa de tots aquests canvis oceanogràfics.

\section{QUINES PROVES N'HI HA?}

$\mathrm{Hi}$ ha diverses tècniques que permeten deduir el clima del passat, i fins i tot precisar la temperatura que hi havia a la superfície del mar en una època determinada.

Les molècules d'aigua poden contenir dos isòtops diferents de l'oxigen: 0-16 o 0-18. Com que la molècula amb oxigen-18 pesa una mica més que l'altra, les molècules d'aigua que passen de líquid a vapor tenen més proporció d'oxigen-16 que les que resten en el líquid. Quan el clima es torna fred, l'aigua del mar s'empobreix d'oxigen-16, doncs el que manca ha condensat $i$ està retingut en forma de gel. Per aquest motiu les closques dels organismes marins contenen més proporció d'O-18 quan el clima és fred que quan és més càlid. Així, analitzant la proporció dels dos isòtops de l'oxigen en les closques dels sediments marins es pot saber aproximadament la temperatura marina en èpoques passades.

Una altra tècnica consisteix en identificar els grans de pol-len dels sediments lacustres i marins. Segons de quines espècies vegetals es tracti, és possible deduir les condicions ambientals que permetien la seva supervivència, especialment les característiques generals del seu clima.
Altres tècniques per saber la temperatura superficial de l'aigua del mar es basen en l'estudi del que queda del plàncton en els sediments. Així, determinades algues unicel-lulars produeixen uns compostos químics (alquenones), que es poden trobar en els sediments, i que són diferents segons la temperatura en la que vivien. Tot i que se'n desconeix el mecanisme, resulta un bon indicador de la temperatura.

\section{UTILITAT D'AQUESTES RECERQUES}

Actualment existeixen models informàtics que permeten simular aproximadament l'evolució del clima de la Terra. El coneixement dels mecanismes de refredament de l'Àrtic, validat mitjançant aquests models, ha de permetre, al seu torn, afinar-los.

De mica en mica va sent possible comprendre i reproduir informàticament l'evolució del clima en temps passats. Però l'interès principal de conèixer els mecanismes d'evolució del clima és intentar preveure la seva possible evolució futura, sobretot tenint en compte l'impacte de les activitats humanes, com les emissions de gasos d'efecte hivernacle.

De moment sabem que l'evolució del clima és deguda a múltiples factors, i no a un de sol. I també que els canvis ràpids necessiten dècades.

Per això, que l'estiu del 2003 fos tan calorós i l'hivern del 2005 tan fred no indica, necessàriament, un canvi de clima, sinó que pot formar part de la variabilitat pròpia d'un sistema tan complex com és el que determina el clima. 